\title{
Family Psychology and Family Law: Introduction to the Special Issue
}

\author{
Neil S. Grossman \\ Dix Hills, New York
}

\author{
Barbara F. Okun \\ Northeastern University
}

This special issue of the Journal of Family Psychology evolved from the work of the Forensic Task Force of Division 43, American Psychological Association, members of which have been studying and working with the emerging, complex issues occurring at the intersection of family psychology and family law. This issue is an endeavor to bring together current research and paradigm development that has relevance not only to family psychologists who have expertise in systems and developmental theories but also to forensic psychologists who have expertise in individual assessment but may lack experience in a systems-ecological framework. A primary goal of this special issue is to introduce readers to new and emerging opportunities for research and practice in the areas where family psychology and family law overlap.

High-profile cases in the news, such as the custody of Elian Gonzalez, Baby M, the custody of O. J. Simpson's children, and the grandparent visitation case in the state of Washington, have heightened public awareness of the complexities of custody and visitation dilemmas. Other high-profile cases focus attention on whether criminal youths should be tried in juvenile or adult court, issues of parental rights and termination thereof, elder care issues and will disputes, and so forth.

The 2000 census (U.S. Census Bureau, 2002) reports an increasing mix of races and ethnic groups within a family as well as an explosive growth of Asian and Hispanic populations. There has been a baby boom in gay and lesbian families as well as a dramatic increase of cohabitating families, single-parent, and grandparent-led families. These changes impact family formation, maintenance, and dissolution and challenge traditional concepts of what a family is and how families function (Melton \& Willcox, 1989; Okun, 1996). Family courts are struggling with unprecedented issues over visitation and custody with lesbian, gay, and cohabitating parents who split up; whether surrogate mothers or donors of eggs or sperm have any parental rights; and the implications for children who are doing well living with a grandparent when a parent is released from jail and wants to reclaim these children.

\section{Psychology and Law}

Psychologists have attempted to influence and/or inform the legal system for some time, most notably in the area of criminal law (Brigham, 1999; Melton, 1987; Ogloff, 1999, 2000; Redding \& Reppucci, 1999). For years there have been tensions between psychology and law. These fields are embedded in different professional cultural systems. Psychology relies on empirical data to support observations about human behavior and development; law relies on information from statutes and case law (legal precedence) to support the needs and interests of clients (often in an adversarial manner). The legal

Neil S. Grossman, independent practice, Dix Hills, New York, and Barbara F. Okun, Department of Counseling and Applied Educational Psychology, Northeastern University.

We would like to thank all of the authors who submitted articles, those whose were accepted, and those whose articles needed further development.

Correspondence concerning this article should be addressed to Neil S. Grossman, 7 Debbie Court, Dix Hills, New York 11746. E-mail: neilgrossman@mindspring.com 
system has been professionally trained to deal with individual members of a family, seeking cause-and-effect linear linkages, whereas family psychology contributes a focus on the family system embedded in larger sociocultural systems, seeking circular causality.

Other variables contribute to the tensions between psychology and law. One such variable is the first-hand experience of members of the legal profession with the application of psychology in courts. For example, legal professionals may have difficulty understanding the difference between testimony that is clinically based and that which is research based. It may be that psychological information is not always clear to lawyers when it is presented at a trial and subjected to cross examination. In courtrooms, the "personhood" of the involved members-such personality factors as charisma, articulation, and expression of self-confidence-may influence the decisions more than the actual evidence.

Redding and Reppucci (1999) researched legal decision making regarding death penalty cases in this country and hypothesized that courts may ignore relevant research when it is counter to the sociopolitical beliefs of a judge. They found that, within this research context, there was a bias effect regarding how much weight judges stated they would give social science evidence. Judges were likely to give the evidence more weight when it was congruent with their own beliefs and less weight when it was at variance with their beliefs. Okun (1999) has confirmed the impact of judicial bias affecting decision making based on her experiences training family court judges for the National Council of Family and Juvenile Court Judges. Because all judges have experiences in family-of-origin and current family systems, the cases they sit on can evoke intense emotional responses.

Fortunately, there also is judicial precedence to utilize social science data in court deliberations (Brigham, 1999; Melton, 1987; Tremper, 1987). Examples are the amicus briefs submitted by the American Psychological Association and the doll preference studies of Kenneth Clark (Clark \& Clark, 1958). Ogloff (2000) believes that, in part, psychology has had a limited impact on law because the range of focus is too limited and there has not been enough meaningful research with a firm theoretical foundation. To ensure that legal professionals attend to what psychology has to offer, our work must be framed in legal terms.

\section{Differences and Overlaps Among Family Psychology, Forensic Psychology, and Family Law}

There are differentiations and overlaps between family psychology and forensic psychology and the areas of family law that are pertinent to both specialities. The family psychology specialty is defined as involving the understanding of families, couples, individuals, groups, and organizations in relationship to each other in their development and sociocultural contexts (Division of Family Psychology, 2001). Family psychology contributes to the understanding of families as organizational systems, their component parts, and the interrelationship of these component parts to each other and to larger systems.

Family psychology identifies one area of this specialty as involving Family Law. The description of this area of focus states that "family psychologists must be familiar with law and regulations regarding such issues as custody and visitation; child, spouse and elderly abuse; and ethical relationships with attorneys. If planning to engage in active courtroom work, the family psychologist must be trained in forensic family psychology" (Division of Family Psychology, 2001, p. 10). In addition, formal training "should include knowledge about family law relevant to family psychology; custody; parental competency; childparent bonding psychology; expert witness activities and other forensic consulting roles" (Williams, Kaslow, \& Grossman, 1994, p. 5).

The specialty of forensic psychology focuses on the utilization of sound psychological appraisal to legal and judicial processes and procedures. Forensic psychologists are "engaged regularly as experts and represent themselves, as such in an activity primarily intended to provide professional psychological expertise to the judicial system" (Division of Forensic Psychology, 2000, p. 5). The specialty petition also states that "the distinctiveness of forensic psychology derives from the forensic psychologist's professional obligation to obtain advanced knowledge and skills on the intersection of legal theory, procedures and law with clinical issues, practices and ethics" (p. 6). Forensic psychology 
practice is described as primarily occurring in civil and criminal areas. (Family law is one part of civil law.) The major practice has been in areas of assessment with much less attention paid to treatment (Otto \& Heilbrun, 2002). An examination of the research and journal articles in forensic psychology shows the majority of articles are in criminal law, criminal procedure, evidence-related concerns, jury issues, and mental health law topics (Ogloff, 2000).

Family psychology and forensic psychology certainly overlap in the area of family law, with family psychology emphasizing family adjustment and the interactions between the family and law. This area of family forensic psychology has been discussed by Kaslow (2000) and by Grossman and Okun (2001, 2002). Both specialties are concerned with most areas of family law: abuse; adoption; alternative families; child support; divorce, including custody, relocation, and conflict resolution; elder law including estate planning; family business; guardianship; juvenile justice; paternity; reproductive and genetic technologies; and other areas such as termination of parental rights. Family forensic psychology is involved in civil and criminal cases when the understanding of family dynamics and family systems is essential, for example, in cases involving visitation to prisons, release programs, and impact of sentencing on family members.

An important difference between forensic psychology and family psychology is that family psychology has a broader integration with family law, whereas forensic psychology has a narrower focus on family law and a broader involvement with criminal law and other areas of civil law.

Family psychology contributes to family law and the judicial system in many ways. The most important contribution relates to translating recent empirical and clinical data about individual and family behavior and development to law personnel. This includes ongoing biological, neurological, and psychopharmacological research findings. Family psychologists can provide information about how family psychology and child, adolescent, and adult developmental psychology interrelate and how the family as context for individual members influences the adjustment of each member. The family systems perspective allows understanding of the ongoing reciprocal influences of individual, family, and larger systems as opposed to a traditional linear conception of causality. Family psychologists consider the individual members of the family, the family as a whole, and the larger systems with which the family interacts. This multisystemic view includes context, culture, generation, race, ethnicity, geographical region, sexual orientation, class, and gender. The family psychologist is trained to perceive and understand the perspective and functioning of each family member within the family context, a concept of multipartiality.

All psychologists who do forensic work regarding families should understand family dynamics. It is important to understand the dynamics of a family, how these dynamics developed over time, and what will help this family stabilize. Traditionally, the legal system has been concerned with assigning culpability and deciding guilt or innocence. This becomes much more complex when issues involving families are under the judicial spotlight. The judge's decision may assign the degree of guilt and appear to settle a case. But frequently the underlying problems continue and the litigants return to court. The continuing problems might be reduced if judges thought of their legal decisions also as an intervention for the family.

\section{Definition and Discussion of Family Forensic Psychology}

Family forensic psychology is a specialty area within family psychology that we define as:

the study of families, members of family units, organizations, and larger systems from a family systems perspective in assessment and intervention regarding interaction with the legal system. Among the areas that assessment and intervention include are prevention, education, evaluation, various forms of conflict resolution, treatment, and outcome assessment. Family forensic psychologists provide expertise to the legal system.

Family forensic expertise is relevant in any area of law that involves families and a systems view. For example, the knowledge of family systems may be important in a murder case, such as when an adult child kills a parent who has sexually abused this child. Family forensics provides consideration of the post-divorce adjustment of the family as well as the legal divorce. 
The best known areas of family forensics involve child custody and family violence. Recent work focuses on lesser known areas of family forensic psychology, such as alternative families, elder law, family business, reproductive technologies, ancillary forensic roles in custody cases such as guardian-ad-litem or parent coordinator and training of lawyers and judges (Grossman \& Okun, 2001, 2002; Kaslow, 2000; Okun, 1999).

An example of multilevel systems thinking expands the legal use of the divorce principle of "the best interests of the child" to the "best interests of the child in relation to the family." Many states assume, when faced with issues of parental relocation post-divorce, that the custodial parent's best interests coincide with the best interests of the child, whereas other states see those interests as separate. Movements toward collaborative divorce and therapeutic jurisprudence are developing across the country, encouraging teamwork among psychologists, lawyers, judges, and divorce parties, rather than adversarial interactions, and a focus on the post-divorce adjustment of the family as well as on the legal divorce (Nurse \& Thompson, 2000; Okun, 1999; Schneider, 1999). These perspectives represent changes in the legal system. Sometimes a small shift in language can change the meaning and dynamics of legal proceedings. For example, considering parenting plans rather than custody and visitation and focusing on comprehensive elder planning and care rather than last wills and testaments contributes to a more positive approach.

Melton (1987) suggested that the best way to reach the legal system is by publishing articles in law reviews. Examples of other ways to impact the legal system are to publish in the form of a bench book (Kenny-Markan \& Vigil, 2002) or a briefing paper for a State Court (Sydlik \& Phalan, 1999) and to train judges (Okun, 1999).

\section{Contents of This Issue of the Journal of Family Psychology}

The eight articles and two comments included in this special issue of a peer-reviewed journal represent many of the conceptual and research topics that illustrate the valuable contributions of family psychology to family law. As in any new field, conceptualization precedes strong research and, as coeditors, we are pleased that the Journal of Family Psychology has given equal weight to conceptual and research submissions.

A significant research methodology is described by Marsha Kline Pruett, Tamra Y. Williams, Glendessa Insabella, and Todd D. Little at Yale University, who present their use of structural equation modeling to examine relations among family dynamics, attorney involvement, and the adjustment of children 6 years or younger at the time of parental separation. These authors discuss the significance of paternal and attorney involvement as well as the nature of the parent-child relationship on child outcomes. In a conceptual article about treatment, Jay Lebow at the Family Institute at Northwestern University, describes a multilevel systems-based treatment model specifically targeted toward those engaged in intractable conflicts over child custody and visitation. This model includes the utilization of therapy contracts, multiple therapy session formats, and working at the interface of family therapy and the legal system to diminish the high risk of children whose parents are engaged in severe conflict.

Two articles address a key issue in family court today, namely, the relocation of the primary custodial parent. The high degree of unemployment, mobility, and separation from extended family and economic issues has spawned new thinking about this topic. Joan B. Kelly, a consultant from California, and Michael Lamb from the National Institute of Child Health and Human Development review developmental issues of a relocating parent for young children. Sanford L. Braver, Ira M. Ellman, and William V. Fabricius from Arizona State University present one of the first research studies to measure the outcomes of parent relocation on college-age offspring. They discuss the development of attachment relationships in infants and toddlers, recent trends in judicial decisions regarding relocations, and creative ways of promoting long-distance relationships between young children and their nonmoving parent.

The article by Brian H. Bornstein at the University of Nebraska discusses the legal and behavioral implications of pregnancy, drug testing, and the Fourth Amendment. In this article, he challenges the government's attempts to regulate pregnant women's conduct, as occurs in identifying and prosecuting those who use illicit drugs, and he discusses possible 
ramifications of the United States Supreme Court's ruling in Ferguson v. City of Charleston (2001). Another cutting-edge area is the impact of new reproductive technologies on custody and visitation decisions. Lita Linzer Schwartz from Pennsylvania State University questions traditional notions of "who the mother is" and reviews recent developments in reproductive technologies and the relevant legal, ethical, and psychological issues.

One area in which family systems psychologists are expert involves the assessment of parental fitness of psychiatrically diagnosed individuals. Corina Benjet (National Institute of Psychiatry, Mexico City), Sandra T. Azar (Pennsylvania State University) and Regina Kuersten-Hogan (Clark University) shift the focus from a predisposing bias of unfitness to a functional contextual analysis of parenting behavior and competency by examining the empirical evidence dealing with the effects of major mental illness on parental fitness. An area of study that has not received much attention is same-sex domestic violence. Michael J. Potoczniak, Jon Etienne Mourot, Margaret Crosbie-Burnett, and Daniel J. Potoczniak from the University of Miami present the legal and psychological aspects of same-sex domestic violence in a multisystemic model.

We have asked two experts in family law to provide commentary from their professional perspectives on these articles in the hopes of furthering the bridge between family psychology and family law. Judge Judith Kreeger, an experienced family court judge in Miami, and Kathryn Kirkland, a family law practitioner in San Francisco, provide thoughtful reflections on the significance of these articles to the overlapping fields of family psychology and family law.

\section{Summary}

As part of a multilevel systemic approach, the authors appearing in this journal suggest implications for social policy and legislation extrapolated from the individual, family, legal, and larger sociocultural systems discussed. The field of family psychology can play a significant leadership role in advocating policies and legislation relevant to the emerging family types and legal dilemmas based on empirical findings.

\section{References}

Benjet, C., Azar, S. T., \& Kuersten-Hogan, R. (2003). Evaluating the parental fitness of psychiatrically diagnosed individuals: Advocating a functional contextual analysis of parenting. Journal of Family Psychology, 17, 252-259.

Bornstein, B. H. (2003). Pregnancy, drug testing, and the Fourth Amendment: Legal and behavioral implications. Journal of Family Psychology, 17, 220-228.

Braver, S. L., Ellman, I. M., \& Fabricius, W. V. (2003). Relocation of children after divorce and children's best interests: New evidence and legal considerations. Journal of Family Psychology, 17, 206-219.

Brigham, J. C. (1999). What is forensic psychology, anyway? Law and Human Behavior, 23, 273-298.

Clark, K. B., \& Clark, M. P. (1958). Racial identification and preference in Negro children. In E. E. Maccoby, T. M. Newcomb, \& E. L. Hartley (Eds.), Readings in social psychology (pp. 602-611). New York: Holt.

Division of Family Psychology, American Psychological Association. (2001). Petition for the recognition of a specialty in professional psychology. Unpublished manuscript.

Division of Forensic Psychology, American Psychological Association. (2000). Petition for the recognition of a specialty in professional psychology. Unpublished manuscript.

Grossman, N. S., \& Okun, B. (2001, August). Family psychology and family law: A systems perspective. Symposium presented at the 109th Annual Convention of the American Psychological Association, San Francisco.

Grossman, N. S., \& Okun, B. (2002, August). New and emerging roles at the intersection of family psychology and law. Symposium presented at the 110th Annual Convention of the American Psychological Association, Chicago.

Kaslow, F. (Ed.). (2000). Handbook of couple and family forensics: A sourcebook for mental health and legal professionals. New York: Wiley.

Kelly, J. B., \& Lamb, M. E. (2003). Developmental issues in relocation cases involving young children: When, whether, and how? Journal of Family Psychology, 17, 193-205.

Kenny-Markan, L., \& Vigil, D. (2002). Bench Book for therapeutic interventions in family court. Retrieved February 1, 2003, from www.azafcc.org/resources.html 
Kirkland, K. (2003). A legal perspective on family psychology and family law: Comment on the special issue. Journal of Family Psychology, 17, 263-266.

Kreeger, J. L. (2003). Family psychology and family law-A family court judge's perspective: Comment on the special issue. Journal of Family Psychology, 17, 260-262.

Lebow, J. (2003). Integrative family therapy for disputes involving child custody and visitation. Journal of Family Psychology, 17, 181-192.

Melton, G. B. (1987). Bringing psychology to the legal system: Opportunities, obstacles, and efficacy. American Psychologist, 42, 488-495.

Melton, G. B., \& Wilcox, B. L. (1989). Changes in family law and family life: Challenges for psychology. American Psychologist, 44, 1213-1216.

Nurse, N., \& Thompson, P. (2000). Collaborative Divorce: A humane, interdisciplinary approach. In L. VandeCreek (Ed.), Innovations in clinical practice: A source book (Vol. 18). Sarasota, FL: Professional Resource Press.

Ogloff, J. R. P. (1999). Law and human behavior: Reflecting back and looking forward. Law and Human Behavior, 23, 1-8.

Ogloff, J. R. P. (2000). Two steps forward and one step backward: The law and psychology movement(s) in the 20th century. Law and Human Behavior, 24, 457-483.

Okun, B. F. (1996). Understanding diverse families. New York: Guilford.

Okun, B. F. (1999). Training family court judges. Unpublished manuscript, National Council of Family and Juvenile Court Judges, Reno, Nevada.

Otto, R. K., \& Heilbrun, K. (2002). The practice of forensic psychology: A look toward the future in light of the past. American Psychologist, 57, 5-18.

Potoczniak, M. J., Mourot, J. E., Crosbie-Burnett, M., \& Potoczniak, D. J. (2003). Legal and psychological perspectives on same-sex domestic violence: A multisystemic approach. Journal of Family Psychology, 17, 252-259.

Pruett, M. K., Williams, T. Y., Insabella, G., \& Little, T. D. (2003). Family and legal indicators of child adjustment to divorce among families with young children. Journal of Family Psychology, 17, $169-180$.

Redding, R. E., \& Reppucci, N. D. (1999). Effects of lawyers' socio-political attitudes on their judgments of social science in legal decision making. Law and Human Behavior, 23, 31-54.

Schneider, A. K. (1999). The intersection of therapeutic jurisprudence, preventive law, and alternative dispute resolution. Psychology, Public Policy, and Law, 5, 1084-1102.

Schwartz, L. L. (2003). A nightmare for King Solomon: The new reproductive technologies. Journal of Family Psychology, 17, 229-237.

Sydlik, B., \& Phalan, A. B. (1999). Interventions for high conflict families: A national perspective. Office of the State Court Administrator, Oregon Judicial Department.

Tremper, C. R. (1987). Organized psychology's efforts to influence judicial policy-making. American Psychologist, 42, 496-501.

U.S. Census Bureau. (2002). U.S. Census Report 2000. Washington, DC: Author. Retrieved from www.census.gov

Williams, B., Kaslow, F., \& Grossman, N. S. (1994). Guidelines for the development of postdoctoral programs in family psychology. Unpublished manuscript.

Received February 18, 2003

Accepted February 18, 2003 